\title{
An investigation into e-learning acceptance and gender amongst final year students
}

\author{
Authors: \\ Willie Chinyamurindi ${ }^{1}$ \\ Herring Shava ${ }^{1}$ \\ Affiliations: \\ ${ }^{1}$ Department of Business \\ Management, University of \\ Fort Hare, South Africa \\ Correspondence to: \\ Willie Chinyamurindi \\ Email: \\ chinyaz@gmail.com \\ Postal address: \\ Private Bag 9083, East \\ London 5200, South Africa \\ Dates: \\ Received: 20 Aug. 2014 \\ Accepted: 10 June 2015 \\ Published: 18 Aug. 2015 \\ How to cite this article: \\ Chinyamurindi, W. \& Shava, \\ H., 2015, 'An investigation \\ into e-learning acceptance \\ and gender amongst final \\ year students', South African \\ Journal of Information \\ Management 17(1), Art. \\ \#635, 9 pages. http://dx.doi. \\ org/10.4102/sajim.v17i1.635

\section{Copyright:} \\ (C) 2015. The Authors. \\ Licensee: AOSIS \\ OpenJournals. This work is \\ licensed under the Creative \\ Commons Attribution \\ License.
}

Read online:
Background: The use of electronic learning (e-learning) systems is gaining popularity especially within a Higher Education (HE) context. However, scholars have identified some factors that affect the utilisation and the acceptance of such systems, one of which is the gender divide, which favours mostly males ahead of females.

Objectives: The objective of this study was to investigate the acceptance of the e-learning system within a South African HE setting, including the influential role of gender in the acceptance of such a system.

Method: Quantitative data was collected through a cross-sectional survey using 113 registered final year students at a South African university who were making use of an e-learning system as part of their teaching delivery. The measuring instrument used was the technology acceptance instrument (TAI) and included measures of computer self-efficacy (CSE), perceived ease of use (PEU), perceived usefulness (PU), and behavioural intention to use (BIU).

Results: The presence of a gender divide was found to exist in this study. Women's ratings of the acceptance of e-learning systems were found to be slightly higher than those of the male respondents. In addition to this, elements of the TAI were found to be related to one another.

Conclusion: The study concludes by arguing that lecturers and facilitators need to pay attention to usage patterns of e-learning systems as they affect how such systems are adopted by their students. Therefore, preceding student acceptance of electronic learning systems should be efforts to address any issues that affect the acceptance and effective utilisation of such systems.

\section{Introduction}

Information Communication Technology (ICT) is being incorporated by educational institutions with the aim of aiding the learning process. Most common are those systems that strive to meet the educational needs and goals in the delivering of teaching referred to, in this context, as electronic learning (e-learning) (O'Neill, Singh \& O'Donoghue 2004). E-learning systems are those that incorporate the use of technology to aid instructional content or teaching delivery (Moore, Dickson-Deane \& Galyen 2011). The advantages of such systems are widely documented. Sun and Zhang (2006) argue that e-learning systems address the constraints of time and distance ultimately allowing students to control their individual learning at their own convenience (Cross 2004). Saadé and Bahli (2005) highlight e-learning systems as using features such as bulletin boards, chat rooms, private email, course content management, quizzes and peer assessment. These bulletin boards not only help to facilitate teaching practice but also to enhance interaction between faculty and its students. According to McNeil, Robin and Miller (2000) all these features create a unique learning experience, given also that sound, video and interactive media can be incorporated.

The focus of this study is on understanding student utilisation of e-learning systems at a rural university in the Eastern Cape Province of South Africa. The rationale for this is motivated by two factors. Firstly, empirical evidence shows that the success of an e-learning system is dependent on its full utilisation. As academics who have been using ICTs such as e-learning in teaching delivery, the authors were interested in ascertaining the usage of such systems from the student's perspective. This can be beneficial in enhancing the student learning experience. Secondly, the authors were interested in the role that gender plays in the utilisation of such e-learning systems. Literature exists in South Africa detailing the existence of gender inequality in various economic and social sectors (Moletsane \& Reddy 2008). Such gender inequality has led to calls for research on the acceptance of technology utilisation, especially in the higher education setting (South African Government Communications 1996). 
The structure followed in this article is, firstly, to put this research into context. Secondly, the theoretical framework underlying this study is presented leading to the research hypotheses. Thirdly, the research design and methodology section follow. Finally, the results, discussion and a conclusion are presented.

\section{Putting this research into context}

The authors of this article are lecturers in the Department of Business Management at a South African university located in the Eastern Cape Province. Their duties entail giving lectures and tutorials for a module called General Management (BEC 322) to a group of 120 final year students. Traditionally, the module has been taught via face-to-face delivery. Owing to personal convictions, it was decided to create new strategies and use tools that improve teaching delivery. The interest was in the use of technology as one of those tools that can potentially aid teaching delivery. This focus fits within the agenda to be found in higher education globally, where the impact of technology on the creation, dissemination, quality, and evaluation of knowledge is deemed important (Rienties, Brouwer \& Lygo-Barker 2013).

As part of the evaluation of the module and the subsequent usage of technology in teaching delivery, the interest was on measuring and understanding the acceptance of technology delivery amongst the university's students. Technology acceptance issues have been cited as a cause for resistance based on the perceptions of end-users (Hardgrave \& Johnson 2003). Therefore, identifying influential factors on technology acceptance was deemed important and focal for both researchers and practitioners (Hsiao \& Yang 2011). For this reason, the authors were interested in identifying and studying the variables that influence technology acceptance in teaching delivery.

Such evaluative feedback would prove useful for two reasons. Firstly, the feedback would help improve future offerings of the module. Secondly, feedback would also form a useful component of a teaching portfolio. A teaching portfolio is viewed as a collection of evidence of descriptions, documents, and examples of what is good teaching (De Rijdt et al. 2006). Such a portfolio has the potential to showcase not only professional capacity but also to serve as an instrument for appraisal, tenure and promotion (Wright, Knight \& Pomerleau 1999). In the authors' view, this study offers potential for effective classroom delivery within, and outside, the classroom for both the student and the lecturer.

However, the attention of the authors was shifted towards the role gender plays in the classroom for two reasons. Firstly, was a subjective reflection from one of our female students enrolled in the authors' class. This comment came after using technology in teaching delivery:

'Sir, I am from a rural area called Cofimvaba, I have never imagined I would use computer systems like Blackboard so well. Not bad for a girl child, hey Sir'.
This view from this student ignited the interest of the authors into the role gender can play not only with classroom learning but also the utilisation of ICTs such as e-learning. Secondly, literature exists detailing this gendered view not only in society but also in the classroom. For instance, Mahlomaholo (2011) highlighted how the plight of women is at the centre of social transformation in South Africa. This gave birth to the formation of a government department, the Department of Women, Children and Persons with Disability which was set up to deal with issues that affect women, girls and the vulnerable. Despite these efforts, gender inequality is believed to still be prevalent in various sectors and situations in South Africa such as the economy (Hlekiso \& Mahlo 2006), corporate sector (Moletsane \& Reddy 2008), service delivery (Steyn 2012), training and development (Chinyamurindi \& Louw 2010), and within the classroom (Hammond et al. 2007; Mahlomaholo 2011).

This research answers calls for studies that focus on the role of science and technology on the lives of people (Reddy et al. 2013) particularly within education research (Flipsen \& van der Weide 2009). Interest is focussed on the acceptance and experience of technology utilisation within a learning context. The interest in studying ICT acceptance and gender together is motivated by calls for research on how ICT can be used to overcome barriers such as inequity for the purpose of redress (Mdlongwa 2012). This article pays attention to a barrier, gender inequity, which characterises not only South African society but also the education landscape (Hammond et al. 2007; Mahlomaholo 2011). The next section explores the theoretical background upon which this research hinges. The focus is on how such inequity affects the utilisation of technology by a sample of students who use ICT as part of their learning experiences.

\section{Theoretical background}

An important theoretical consideration specific to the utilisation of technology is the Technology Acceptance Model (Davis 1989; Venkatesh \& Davis 2000) referred to hereafter as TAM. This model consists of two beliefs that determine attitudes to adopt a new technology, perceived usefulness and perceived ease of application. The attitude towards adoption depicts the prospective adopter's positive or negative orientation and/or behaviour about adopting a new technology (Venkatesh \& Davis 2000). Table 1 outlines the constructs of the TAM including a brief definition based on supporting literature.

The TAM is chosen as a framework to predict and explain human behaviour concerning technology acceptance (Ajzen \& Fishbein 1980; Gupta \& Jana 2003). The TAM is deemed suitable as a framework for this study given its perceived robustness, from the user's point of view, in predicting individual intentions in relation to technology adoption (Ong \& Lai 2006). The thinking here is that human behaviour such as individual beliefs, attitudes, and intentions (Lin, Fofanah \& Liang 2011) affect actual ICT use (Chen, Gillenson \& Sherrel 2002; Gefen, Karahanna \& Straub 2003; Karahanna, 
TABLE 1: Elements of the Technology Acceptance Model.

\begin{tabular}{ll}
\hline TAM Construct & Definition(s) \\
\hline Computer self-efficacy (CSE) & $\begin{array}{l}\text { An individual's perceptions of his or her ability } \\
\text { to use computers in the accomplishment of a } \\
\text { task rather than reflecting simple component } \\
\text { skills' (Compeau \& Higgins 1995). }\end{array}$ \\
Perceived usefulness (PU) & $\begin{array}{l}\text { This is defined as the degree to which a person } \\
\text { believes that using a particular technology } \\
\text { would enhance their performance (Davis 1989). }\end{array}$ \\
Perceived ease of use (PEU) & $\begin{array}{l}\text { This is defined as the degree to which a person } \\
\text { believes that using the system would be free of } \\
\text { effort (Davis 1989). }\end{array}$ \\
Behavioural intention to use (BIU) & $\begin{array}{l}\text { This is defined as the predictor of human } \\
\text { behaviour to perform a behaviour (Fishbein } \\
\text { \& Ajzen 1975). From a subjective angle, it is } \\
\text { also defined as a person's perception of social } \\
\text { pressure regarding the performance of the } \\
\text { behaviour (Ajzen \& Fishbein 1980). }\end{array}$ \\
\hline
\end{tabular}

Straub \& Chervany 1999). This thinking gives attention to investigating such behaviour, given its bearing on actual system use and adoption.

The TAM is built around the Theory of Reasoned Action (TRA) (Fishbein \& Ajzen 1975), which suggests how individual behaviour is initiated by its behavioural intention to perform a particular task. The result of this is that individual behavioural intention determines one's attitude and subjective norms regarding the behaviour in question (Fishbein \& Ajzen 1975). The TRA also posits that intention to act determines behaviour, and causal link is believed to exist between the two (Venkatesh \& Davis 2000). The attitudebehavioural intentions relationship, as espoused in constructs of the TAM, assume that all use being equal, intentions to use technology can be formed based upon positive usage of the technology. The PU-BIU relationship assumes this and has been shown to have a positive or negative influence on individual behaviour in organisations (Robinson, Marshall \& Stamps 2005). The research therefore seeks to measure perceptions and relationships amongst the constructs of the TAM, with gender as a moderating variable leading to an empirical investigation into relationships between TAM constructs and the moderating role of gender.

For the purpose of this article, ICTs will refer to electronic learning (e-learning) viewed as a learning experience delivered or enabled by electronic technologies, including the Internet, intranets, and extranets (Govindasamy 2002). The e-learning system referred to and adopted in this research refers to a general management course placed on a Learning Management System (LMS) Blackboard. Learning materials such as the learner guide, lecture notes, tutorials, and quizzes were all placed on Blackboard, and each student given equal access. In addition to these, videos, podcasts and audio downloads were placed on the BlackBoard platform. The LMS allowed for collaboration between the students and the lecturer, opportunities to share ideas, tips to solve problems, and explanation of any course-related issues (Schoonenboom 2014). Given this, backdrop the research question set for this study reads:

How is e-learning acceptance conceptualised within an educational context and to what extent is gender a moderating variable to this (if any) amongst a sample of students?

\section{Literature review Empirical work using TAM constructs \& gender}

With reference to relationships amongst TAM constructs, a number of studies in the past three decades support the existence of a relationship (e.g. Agudo-Peregrina, HernándezGarcia \& Pascual-Miguel 2014; Chen et al. 2002; Davis 1989; Malhotra \& Galletta 1999; Moon \& Kim 2001; Venkatesh \& Davis 2000). In summary, empirical studies show CSE to influence PEU (e.g. Grandon, Alshare \& Kwun 2005; Jong \& Wang 2009; Ong \& Lai 2006). In turn, PEU has been found to have a significant effect on PU (e.g. Venkatesh \& Davis 2000). Subsequently, a positive relationship has been found to exist between PU and BIU (e.g. Joo \& Sang 2013; Lee \& Lehto 2013). The thinking here is that a student's confidence in performing specific tasks through the e-learning system coupled by easy access and ease of use of the system will help that student not only navigate through the system but will affect future possible use (Compeau \& Higgins 1995; Venkatesh \& Davis 2000). Calls have been made for studies on the utility and applicability of the TAM and its constructs, especially within an educational setting (Ong \& Lai 2006; Pituch \& Lee 2006; Sánchez \& Hueros 2010). This study seeks to answer these calls within a South African context.

There appears to be a general consensus of the existence of a gender divide that favours males. In a study by Cherian and Shumba (2011) it was found that males show more positive attitudes towards science than females. Flipsen and van der Weide (2009) suggest that women have fewer options and opportunities to engage in new technologies largely because of their social position. Part of the problem is grounded in traditional ways of thinking that mostly favour males ahead of women (McGregor \& Bazi 2001). This thinking implies that the inability to use and access technology in the long run affects not only performance expectancy but also the intention to use technology for learning (Brown \& Licker 2003; Pavon \& Brown 2010). This research appears to support the existence of gender-based differences in decision-making behaviour as theorised in previous work (e.g. Claes 1999; Feingold 1994).

Previous empirical work has found gender to have a moderating effect when it comes to the acceptance of ICTs (e.g. Chinyamurindi \& Louw 2010; Okazaki \& Renda dos Santos 2012; Ong \& Lai 2006; Srite \& Karahanna 2006; Venkatesh et al. 2003). Women in such circumstances have been disadvantaged when it comes to the adoption of technology ahead of their male counterparts. The underlying premise for this finding could be the reason why gender can also exist as a variable that has linkages with socio-economic standing (Lin et al. 2011). The thinking here is that, because of their socio-economic standing in society, women adopt technology differently to men (Sierpe 2005).

A number of studies find women to be disadvantaged when it comes to the adoption and usage of technology. For instance, Agboola (2013) found women to have less confidence than 


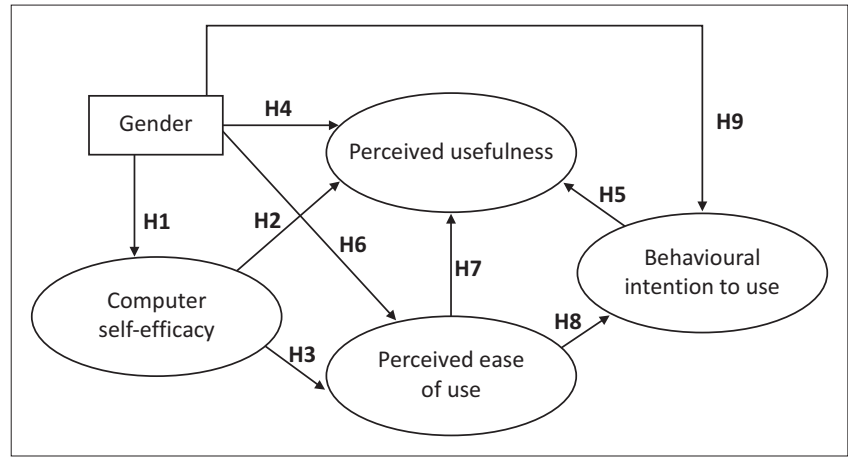

FIGURE 1: Research model.

men in their adoption of technology, although empirical work showed that women spend more time online than men (Pew Internet and American Life Project 2005). Furthermore, women have been found to have higher ratings of anxiety when it comes to using technology (Wild et al. 2012). This has often led to the view that ICTs are a male preserve (Nobel 2007; Tahmincioglu 2008) resulting in women having lower ratings with regard to constructs of the TAM (Ong \& Lai 2006).

Additionally, research also finds men to rate the usefulness of technology higher than women (Venkatesh \& Morris 2000). This could possibly be the reason why women are more anxious about using computers than their male counterparts (Broos 2005). In some instances, this may lead to women showing higher ratings of emotion when it comes to using technology than their male counterparts (Fisk \& Stevens 1993). Conversely, women have been found to be motivated more by factors such as process issues (PEU) and the social aspect (subjective norms) than men (Ong \& Lai 2006). Based on all these theories the following hypotheses are set for this research:

Hypothesis 1: Men rate CSE higher than women.

Hypothesis 2: CSE influences PU of e-learning indifferently between genders.

Hypothesis 3: CSE influences PEU of e-learning indifferently between genders.

Hypothesis 4: Men rate PU of e-learning higher than women.

Hypothesis 5: PU influences BIU e-learning indifferently between genders.

Hypothesis 6: Men rate PEU of e-learning higher than women.

Hypothesis 7: PEU influences PU of e-learning indifferently between genders.

Hypothesis 8: PEU influences BIU e-learning indifferently between genders.

Hypothesis 9: Men rate BIU e-learning higher than women.

Given the implications of these hypotheses, Figure 1 presents a research model in view of the presented hypotheses:

\section{Research methodology}

The authors of this study subscribe to the notion that 'causes' determine the 'outcomes' (Creswell 2014:7). Thus, in undertaking this study, a post positivist worldview was adopted. Subsequently, this study is of a quantitative design in nature. Quantitative studies seek to explain theories through investigating relationships amongst different study variables. Such variables in quantitative studies are measured through instruments which facilitate the coding of data that in turn leads to statistical data analysis in the form of descriptive and inferential methods (Creswell 2014). This research was carried out following the aforementioned approach.

To gather primary data, researchers made use of a questionnaire. Questionnaires were deemed to be cheap and cost effective allowing for a wider reach. This met our budgetary concerns as researchers. Through a questionnaire, responses are able to be gathered in a standardised manner using already existing measures of the TAM known to be 'well-established, robust, powerful and parsimonious models for predicting user acceptance' (Venkatesh \& Davis 2000:186).

\section{Research instrument}

The instrument used (18 items) was the TAM which is viewed as the prime tool for testing user acceptance of new technologies (Green 2005) and has been extensively used in various contexts e.g. studying e-government implementation (Lin et al. 2011), within healthcare (Pai \& Huang 2011), in the South African corporate sector (Chinyamurindi \& Louw 2010), and across a wide range of educational settings (Ong \& Lai 2006; Pituch \& Lee 2006; Sánchez \& Hueros 2010). Students were informed that participating in the study was voluntary and ethical consent had to be given through signing an ethical agreement form. A total of 120 students were enrolled for the course, and all the students were given the questionnaire to be part of the research. A total of 113 questionnaires were deemed usable as seven questionnaires had missing data. For taking part in the research, the students all received an incentive (Singer \& Bossarte 2006) in the form of 5 marks out of a possible 25 marks for class participation as part of their assessment. The instrument consisted of 18 items on a five-point Likert scale.

\section{Reliability test Reliability}

Merriam (2009) suggests that issues of reliability and validity be addressed when undertaking research as data are collected, analysed and interpreted. Cronbach's alpha coefficient (Cronbach 1951) was used as a test for internal consistency. Santos (1999) argues that the higher the Cronbach value, the more reliable the instrument. He adds that 0.7 is an acceptable reliability coefficient. However, 0.7 has been contested as an acceptable Cronbach value by some statisticians (e.g. Charter 2000; Cortina 1993; Duhachek \& Iacobucci 2004; Hakstian \& Whalen 1976; Van Zyle, Heinz \& Nel 2000). Leontitsis and Pagge (2007:336) thus caution that much of this deadlock is motivated by the 'experience and intuition' of the researcher. 
In this study, the Cronbach alpha was calculated for the 18item questionnaire and found to be 0.74 . Since the Cronbach alpha coefficient average for student acceptance of technology was 0.74 and that 0.7 is deemed as an acceptable reliability coefficient, the coefficient for this study suggests that the data gathering instrument had a measure of reliability. Content and face validity was followed in this research. This consisted, amongst others, of a subjective impression of items in the questionnaire. A pilot study was used to pre-test the questionnaire amongst a sample of 25 students not included in the main study. Suggestions and amendments from this process were taken on board with regard to the main study. These included aspects of simplicity and clarity of questions and a detailed suggestion of the need for an introductory section of the questionnaire to help students. The researcher (also lecturer of the BEC 322 module) was present at the time of filling out the questionnaire enabling him to attend to any student concerns that arose out the tests for content and face validity.

\section{Data analysis}

Analysis was shared between the authors of this paper and a professional statistician using the Statistical Package for the Social Sciences (SPSS), Version 21. The data analysis was split according to the hypothesis. The first category hypotheses (1, 4,6 , and 9) involved testing ratings of the TAM constructs by gender and were really comparative in nature. Consideration here was given to the need to generate descriptive data in the form of means and standard deviations. A comparison in the means would be able to answer these hypotheses through an exploration of the data. Thereafter, tests of normality of data were considered with reference to the ratio of skewness and kurtosis (Pallant 2010). As a general rule, if the ratio of skewness and kurtosis to their respective standard errors (SE) is not within the range of -1.96 to +1.96 , the data are probably not normally distributed (Razali \& Wah 2011). Regarding statistical significance, the value was set at a 95\% confidence interval level $(p \leq 0.05)$.

The second set of hypotheses $(2,3,5,6,7$, and 8) were analysed using Multivariate Analysis of Variance (MANOVA). This was carried out with gender (male and female) as independent variable and the mean scores of the scales serving as dependent variables. Tabachnick and Fidell (2007) posit that MANOVA tests are useful for ascertaining whether or not, on a combination of dependent variables, mean differences amongst groups of people are likely to have occurred by chance. These conditions are especially applicable to hypotheses (1, 4, 6, and 9). In addition to tests of statistical difference, tests of effect sizes (Cohen 1988) were used to determine the significance of the relationships of these findings (Steyn 2000).

\section{Results}

With regards to descriptive statistics about the data, Table 2 summarises the findings. From the 120 initial questionnaires collected, 113 were deemed usable (94\%) with 7 rejected, as
TABLE 2: Biographical characteristics.

\begin{tabular}{lc}
\hline Variable & $\boldsymbol{n}=\mathbf{1 1 3}$ \\
\hline Gender & \\
Male & 49 \\
Female & 64 \\
Computer Knowledge & \\
Great & 24 \\
Good & 74 \\
Average & 15 \\
Not so Good & - \\
e-learning Experience & \\
$>1$ year & 49 \\
1-2 years & 34 \\
$<3$ years & 30 \\
\hline
\end{tabular}

TABLE 3: Ratings of Technology Acceptance Model Constructs by Gender.

\begin{tabular}{lcccccc}
\hline TAM Construct & \multicolumn{2}{c}{ Men $(n=49)$} & & \multicolumn{3}{c}{ Women $(n=64)$} \\
\cline { 2 - 3 } \cline { 7 - 8 } & M & SD & & M & SD & Sign. \\
\hline CSE & 2.525 & 0.589 & & 2.648 & 0.483 & $0.226^{*}$ \\
PU & 1.877 & 0.582 & & 2.023 & 0.724 & $0.252^{*}$ \\
PEU & 2.086 & 0.496 & & 2.257 & 0.496 & $0.099^{*}$ \\
BIU & 1.734 & 0.604 & & 1.835 & 0.636 & $0.394^{*}$ \\
\hline
\end{tabular}

$\mathrm{M}$, mean, SD, standard deviation; CSE, computer self-efficacy; PU, perceived usefulness; PEU, perceived ease of use; BIU, behavioural intention to use

$*$, Correlations are significant at $p<0.05$

TABLE 4: Tests of normality.

\begin{tabular}{lcccc}
\hline Test & CSE & PU & PEU & BIU \\
\hline$n$ & 113 & 113 & 113 & 113 \\
Skewness & 0.272 & 1.255 & 0.132 & 0.611 \\
Kurtosis & 0.343 & 3.331 & 0.004 & 0.253 \\
Standard error of Kurtosis & 0.451 & 0.451 & 0.451 & 0.451 \\
\hline $\begin{array}{l}\text { CSE, computer self-efficacy; } \\
\text { behavioural intention to use }\end{array}$ & & & &
\end{tabular}

they were either not filled out correctly or the students did not prefer to be part of the study. A majority of the respondents rated themselves as having good computer knowledge with none of the respondents citing their computer knowledge to be not so good. The majority of the respondents have been using the e-learning system for over a year, as shown in Table 2 .

The effects of gender upon CSE, PU, PEU and BIU were examined using mean scores and standard deviations (see Table 3). Significant gender differences were found for CSE, PU,PEU and BIU. These differences indicate that women rated computer self-efficacy, perceived usefulness, perceived ease of use, and behavioural intention to use e-learning slightly higher than men. As a result, Hypothesis 1, Hypothesis 4, Hypothesis 6 and Hypothesis 9 are not supported.

With regards to tests of normality, Table 4 presents the data from the analyses. In the study, the ratios of skewness and kurtosis to their respective standard errors have been calculated and the ratings of CSE and PEU fall within the gazetted range (Razali \& Wah 2011) suggesting that the data are approximately normally distributed. However, ratings of BI display evidence of skewness, although the ratings fall within the desired range with regards to kurtosis. PU ratings were ruled not to be normally distributed as the ratios of skewness and kurtosis to their respective standard errors 
TABLE 5: Multivariate tests.

\begin{tabular}{lcccc}
\hline Hypotheses & Wilk's $\wedge$ & $\boldsymbol{F}$ & $\boldsymbol{P}$-value & Multivariate $\boldsymbol{\eta}^{2}$ \\
\hline 2 (CSE-PU) & 0.912 & 2.110 & 0.353 & 0.019 \\
3 (CSE-PEU) & 0.964 & 2.080 & 0.130 & 0.036 \\
5 (PU-BIU) & 0.986 & 0.762 & 0.469 & 0.014 \\
7 (PEU-PU) & 0.973 & 1.550 & 0.217 & 0.027 \\
8 (PEU-BIU) & 0.975 & 1.418 & 0.247 & 0.025 \\
\hline
\end{tabular}

CSE, computer self-efficacy; PU, perceived usefulness; PEU, perceived ease of use; BIU, behavioural intention to use

$*$, Correlations are significant at $p<0.05$

were calculated and found to be outside the desired and/or gazetted range (Razali \& Wah 2011).

The next set of analysis sought to test influences amongst determinants of the TAM by gender. Notably, this included: CSE - PU; CSE - PEU; PU - BIU; PEU - PU, and PEU - BIU. The aim here was to test if these determinants of the TAM relate indifferently by gender. To achieve this, Multivariate Analysis of Variance (MANOVA) was conducted using an alpha test of 0.05. MANOVA was deemed appropriate here to determine the significance of differences between TAM determinants and gender (Aiken \& West 1991). Wilk's Lambda was also used to test whether population mean vectors for all groups were likely to be identical to those of the sample mean vectors for the different groups (Field 2013; Tabachnick \& Fidell 2007).

With regard to the relationship between CSE - PU by gender and based on the MANOVA results (Wilks' Lambda $=0.912$; $\mathrm{F}=(2.11)=1.052 ; p$-value $=0.353>0.05)$, CSE was found to influence PU indifferently between genders thus the null hypothesis (H2) is supported. Table 5 summarises additional MANOVA test results undertaken to test the null hypothesis 3 (CSE - PEU); hypothesis 5 (PU - BIU); hypothesis 7 (PEU PU) and hypothesis 8 (PEU - BIU) by gender. Overall, results with regard to hypotheses 2, 3, 5, 7, and 8 indicate the absence of a significant effect of gender on TAM constructs namely, CSE, PU, PEU, BIU denoted by the p-value column with all $\mathrm{p}$-values above the significant level of $p=0.05$.

\section{Discussion, implications, contributions \& limitations}

The aim of this study was to understand student utilisation of e-learning systems at a rural university in the Eastern Cape Province of South Africa.

The presence of a gender divide was found to exist in this study where women were found to rate other TAM constructs higher than men, thereby contradicting other empirical studies. This finding contradicts previous findings that prescribe gender as a moderating effect (Srite \& Karahanna 2006; Venkatesh et al. 2003) as well as a prevailing socioeconomic context (Lin et al. 2011) affecting the acceptance of technology and ICTs. Uniquely, this gender divide in relation to ICTs and technology was not found to exist within a South African classroom context and thus further disputes previous studies (e.g. Hammond et al. 2007; Mahlomaholo 2011). Instead, where the gender divide was noted, it was found to favour females ahead of males (evident in H1, H4, H6, and H9 statistical results). This finding represented a significant move away from previous work that found a gender divide favouring males ahead of females (e.g. Cherian \& Shumba 2011; Flipsen \& van der Weide 2009; McGregor \& Bazi 2001; Ong \& Lai 2006).

The study has a number of implications. Firstly, with regard to teaching practice, constructs of TAM can be useful in revealing aspects that need attention concerning e-learning usage. Student confidence in using such systems has a bearing on how the system will be perceived to be of easy access and use. In turn, this affects not only students' continual navigation but also the possible use of such systems such as e-learning (Compeau \& Higgins 1995; Venkatesh \& Davis 2000). Secondly, our study contributes to the literature by providing insight into individual and psychological factors that influence the adoption and use of technology by testing the TAM empirically. This study also represents a call for studies that examine the utility and applicability of the TAM and its constructs especially within an educational setting (Ong \& Lai 2006; Pituch \& Lee 2006; Sánchez \& Hueros 2010).

This study offers contributions. Firstly, within a South African context it fits within the agenda for studies that cover technology utilisation (Rienties et al. 2013) and gender issues in the classroom (Hammond et al. 2007; Mahlomaholo 2011). Particularly the findings of this work highlight the need to overcome barriers with regards to technology adoption. Addressing these barriers can affect system utilisation and individual optimal use. Secondly, the findings of this study have informed the authors' teaching practice and made them come up with practical interventions to help students with regards to technology adoption. They have started offering tutorials and personalised assistance for students addressing aspects of the TAM constructs. The thinking here is that aspects of the TAM can be a potential cause for resistance based on the perceptions of end-users (Hardgrave \& Johnson 2003; Malhotra \& Galetta 1999). Based on this, the authors asked for assistance from their Teaching and Learning Centre to offer courses that address basic issues such as computer appreciation skills and how to help students manage their learning using technology. To this end, the current study was a useful window in revealing not only challenges affecting technology adoption but also practical interventions.

Some limitations exist with this work. Firstly, the sample is not generalisable to the entire population of students using technology within a higher education setting. Some factors relating to this can be due to the nature of the parent institution which attracts predominantly black students. Notably, other race groups found within the South African society are not found within the sample, a reason being the demographics at the authors' institution. This skewed sample seriously compromises this study and limits its generalisability. Secondly, though the TAM is viewed as a robust predictor of intention (Ong \& Lai 2006) other theoretical frameworks and variables could have been used to add to the predictive power of the TAM. For instance, there is work advocating for 
the extended TAM (e.g. Cheung \& Vogel 2013) incorporating factors such as compatibility (Moore \& Benbasat 1991), perceived resource (Mathieson 1991), and sharing (Wasko \& Faraj 2005). Although this is a limitation in this study, it can also represent an opportunity for future research.

Future research could take a number of approaches. Firstly, this can include a qualitative investigation into aspects of technology adoption tapping into understanding the experience of technology usage. This can take the form of structured or unstructured interviews into understanding the meaning of behaviours and experiences, such as using technology in a natural flow of a conversation (Patton 2002). This can allow for the triggering of memories, reflection on experiences, elaboration of ideas, and clarification of responses (Rubin \& Rubin 2005). Based on this study, an interesting angle to investigate could be the experience of male end-user experience of an e-learning system. This is especially relevant as this study found ratings of TAM constructs to be lower for males than females, a finding that is a stark contrast to previous findings explored in the literature review; a qualitative angle can be useful in understanding this. Secondly, given the status of the authors' university as a previously disadvantaged rural institution it would be interesting to conduct a comparative study using a more affluent urban university. The comparison can be used as a basis to ascertain the influence of university affluence and location towards individual adoption of technology. The outcome of such a study can inform the need to investigate more extraneous variables outside the individual. Finally, as mentioned earlier, more empirical work could include the use of advanced models, with instruments outside the TAM beginning to receive attention (e.g. Cheung \& Vogel 2013).

\section{Conclusion}

The findings of this study point to the great strides that policies of redress have made in empowering females to adopt technology in the classroom. Notably, female participants in this study rate their usage of technology to be higher than their male counterparts against the TAM constructs when using e-learning. However, the study also paints a picture of the need to not neglect paying attention to males, although previous theorising shows support for their positive usage on TAM constructs.

\section{Acknowledgements Competing interests}

The authors declare that they have no financial or personal relationships which may have inappropriately influenced them in writing this article.

\section{Authors' contributions}

Both W.C. (University of Fort Hare) and H.S. (University of Fort Hare) conceptualised the study and collected the data. H.S. conducted the data analysis. Both authors were equally involved in writing up of the article and dealing with comments from the reviewers and the Editorial Board.

\section{References}

Agboola, A.K., 2013, 'A study of socio-demographics effects on e-learning adoption among lecturers', International Journal of Emerging Technology and Advanced Engineering 3(4), 651-661.

Agudo-Peregrina, Á.F., Hernández-García, Á. \& Pascual-Miguel, F.J., 2014, 'Behavioral intention, use behavior and the acceptance of electronic learning systems: Differences between higher education and lifelong learning', Computers in Human Behavior 34, 301-314. http://dx.doi.org/10.1016/j.chb.2013.10.035

Aiken, L.S. \& West, S.G., 1991, Multiple regression: Testing and interpreting Interactions, Sage Publications, Newbury Park.

Ajzen, I. \& Fishbein, M., 1980, Understanding attitudes and predicting socia behaviour, Prentice-Hall, Englewood Cliffs.

Broos, M.A., 2005, 'Gender and information and communication technologies (ICT) anxiety: Male self-assurance and female hesitation', Cyber Psychology \& Behavior 8(1), 145-166. http://dx.doi.org/10.1089/cpb.2005.8.21

Brown, I. \& Licker, P., 2003, 'Exploring differences in Internet adoption and usage between historically advantaged and disadvantaged groups in South Africa', Journal of Global Information Technology Management 6(4), 6-26. http://dx.doi. org/10.1080/1097198X.2003.10856358

Charter, R.A., 2000, 'Confidence interval formulas for split-half reliability coefficients', Psychological Reports 86, 1168-1170. http://dx.doi.org/10.2466/ pr0.2000.86.3c.1168

Chen, L., Gillenson, M.L. \& Sherrell, D., 2002, 'Enticing online consumers: An extended technology acceptance perspective', Information \& Management 39(8), 705-719. http://dx.doi.org/10.1016/S0378-7206(01)00127-6

Cherian, L. \& Shumba, A., 2011, 'Sex differences in attitudes toward science among Northern - Sotho speaking learners in South Africa', Africa Education Review 8(2), 286-301. http://dx.doi.org/10.1080/18146627.2011.603241

Cheung, R. \& Vogel, D., 2013, 'Predicting user acceptance of collaborative technologies: An extension of the technology acceptance model', Computers \& Education 63, 160-175. http://dx.doi.org/10.1016/j.compedu.2012.12.003

Chinyamurindi, W.T. \& Louw, G.J., 2010, 'Gender differences in technology acceptance in selected South African companies: Implications for electronic learning', South African Journal of Human Resource Management 8(1), 1-7. http://dx.doi. org/10.4102/sajhrm.v8i1.204

Claes, M.T., 1999, 'Women, men, and management styles', International Labour Review 138(4), 431-446. http://dx.doi.org/10.1111/j.1564-913X.1999. tb00396.x

Cohen, J., 1988, Statistical power analysis for the behavioral sciences, 2nd edn., Lawrence Erlbaum, New Jersey.

Compeau, D.R. \& Higgins, C.A., 1995, 'Computer self-efficacy: Development of a measure and initial test', MIS Quarterly 19(2), 189-211. http://dx.doi. org/10.2307/249688

Cortina, J.M., 1993, 'What is coefficient alpha? An examination of theory and application', Journal of Applied Psychology 78, 98-104. http://dx.doi. org/10.1037/0021-9010.78.1.98

Creswell, J.W., 2014, Research design: Qualitative, quantitative, and mixed methods approaches, 4th edn., SAGE Publications, Inc., Thousand Oaks.

Cronbach, L.J., 1951, 'Coefficient alpha and the internal structure of tests', Psychometrika 22(3), 297-334. http://dx.doi.org/10.1007/BF02310555

Cross, J., 2004, 'An informal history of e-learning', On the Horizon 12(3), 103-110. http://dx.doi.org/10.1108/10748120410555340

Davis, F., 1989, 'Perceived usefulness, perceived ease of use, and user acceptance of information technology', MIS Quarterly 13(3), 318-339. http://dx.doi. org $/ 10.2307 / 249008$

De Rijdt, C., Tiquet, E., Dochy, F. \& Devolder, M., 2006, 'Teaching portfolios in higher education and their effects: An explorative study', Teaching and Teacher Education 22, 1084-1093. http://dx.doi.org/10.1016/j.tate.2006.07.002

Duhachek, A. \& Lacobucci, D., 2004, 'Alpha's standard error (ASE): An accurate and precise confidence interval estimate', Journal of Applied Psychology 89, 792-808. $\mathrm{http}: / / \mathrm{dx}$.doi.org/10.1037/0021-9010.89.5.792

Feingold, A., 1994, 'Gender differences in personality: A meta-analysis', Psychological Bulletin 116(3), 429-456. http://dx.doi.org/10.1037/0033-2909.116.3.429

Field, A., 2013, Discovering statistics using IBM SPSS statistics, 4th edn., Sage, London.

Fishbein, M. \& Ajzen, I., 1975, Belief, attitude, intention, and behavior: An introduction to theory and research, Addison-Wesley, Reading.

Fisk, S.T. \& Stevens, L.E., 1993, 'What's so special about sex? Gender stereotyping \& discrimination', in S. Oskamp \& M. Costanzo (eds.), Gender issues in contemporary society, Sage, Newbury Park.

Flipsen, N.A. \& van der Weide, T., 2009, 'Implementing gender issues in ICT', Africa Education Review 6(2), 308-323. http://dx.doi.org/10.1080/18146620903274621

Gefen, D., Karahanna, E. \& Straub, D.W., 2003, 'Trust and TAM in online shopping: An integrated model', MIS Quarterly 27(1), 51-90.

Govindasamy, T., 2002, 'Successful implementation of e-learning: Pedagogical considerations', Internet and Higher Education 4, 287-299. http://dx.doi. org/10.1016/S1096-7516(01)00071-9 
Grandon, E., Alshare, O. \& Kwun, O., 2005, 'Factors influencing student intention to adopt online classes: A cross-cultural study', Journal of Computing Sciences in Colleges 20(4), 46-56.

Green, I.F.R., 2005, 'The emancipatory potential of a new information system and its effect on technology acceptance', unpublished PhD thesis, University of Pretoria.

Gupta, M.P. \& Jana, D., 2003, 'E-government evaluation: A framework and case study', Government Information Quarterly 20, 365-387. http://dx.doi.org/10.1016/j. giq.2003.08.002

Hakstian, A.R. \& Whalen, T.E., 1976, 'A K-sample significance test for independent alpha coefficients', Psychometrika 41, 219-231. http://dx.doi.org/10.1007/ BF02291840

Hammond, C., Linton, D., Smink, J. \& Drew, S., 2007, Dropout risk factors and exemplary programs: A technical report, National Dropout Prevention Center Communities in Schools, Inc., Clemson, SC, viewed 20 March 2014, from http:// www.dropoutprevention.org/resource/major_reports/communities_in_schoo s.htm

Hardgrave, B.C. \& Johnson, R.A., 2003, 'Toward an information systems development The case of object-oriented', IEEE Transactions on Engineering Management 50(3), 322-336. http://dx.doi.org/10.1109/TEM.2003.817293

Hlekiso, T. \& Mahlo, N., 2006, 'Wage trends and inequality in South Africa: A comparative analysis', South African Reserve Bank: Labour Market Frontiers 8 , 9-16.

Hsiao, C.H. \& Yang, C., 2011, 'The intellectual development of the technology acceptance model: A co-citation analysis', International Journal of Information Management 31(2), 128-136. http://dx.doi.org/10.1016/j.ijinfomgt.2010.07.003

Jong, D. \& Wang, T.S., 2009, 'Student acceptance of web-based learning system', Proceedings of the 2009 International Symposium on Web Information System and Applications (WISA'09), pp. 533-553, Nanchang, People's Republic of China.

Joo, J. \& Sang, Y., 2013, 'Exploring Koreans' smartphone usage: An integrated mode of the technology acceptance model and uses and gratifications theory', Computers in Human Behavior 29, 2512-2518. http://dx.doi.org/10.1016/j.chb.2013. 06.002

Karahanna, E., Straub, D.W. \& Chervany, N.L., 1999, 'Information technology adoption across time: A cross-sectional comparison of pre-adoption and post adoption beliefs', MS Quarterly 23(2), 183-213. http://dx.doi.org/10.2307/249751

Lee, D.Y. \& Lehto, M.R., 2013, 'User acceptance of YouTube for procedural learning: An extension of the technology acceptance model', Computers and Education 61 193-208. http://dx.doi.org/10.1016/j.compedu.2012.10.001

Leontitsis, A. \& Pagge, J., 2007, 'A simulation approach on Cronbach's alpha statistical significance', Mathematics and Computers in Simulation 73(5), 336-340. http:// dx.doi.org/10.1016/j.matcom.2006.08.001

Lin, F., Fofanah, S.S. \& Liang, D., 2011, 'Assessing citizen adoption of e-Government initiatives next term in Gambia: A validation of the technology acceptance model
in information systems success', Government Information Quarterly 28(2), 271in information systems success', Government Inform
279. http://dx.doi.org/10.1016/j.giq.2010.09.004

Mahlomaholo, S.M.G., 2011, 'Gender differentials and sustainable learning environments', South African Journal of Education 31, 312-321.

Malhotra, Y. \& Galletta, D.F., 1999, 'Extending the technology acceptance mode to account for social influence: Theoretical bases and empirical validation', in Proceedings of the 32nd Hawaii International Conference on System Sciences 1, 1-10, IEEE Computer Society, Washington, DC, Management Review, 14(4), 532550. http://dx.doi.org/10.1109/hicss.1999.772658

Mathieson, K., 1991, 'Predicting user intentions: Comparing the technology acceptance model with the theory of planned behavior', Information System Research 2(3), 173-191. http://dx.doi.org/10.1287/isre.2.3.173

McGregor, E. \& Bazi, F., 2001, Gender mainstreaming in science and technology, viewed 10 January 2014, from https://www.google.co.za/url?sa=t\&rct=j\&q= \&esrc $=s \&$ source $=$ web \&cd $=1 \& c a d=r j a \& u a c t=8 \& v e d=0 C B w Q F j A A a h U K E w j \_4 o q b$ hd3GAhXI7ROKHTL1CMo\&url=http $\% 3 \mathrm{~A} \% 2 \mathrm{~F} \% 2$ Funidadedamullereciencia.xunta. es $\% 2$ Fsites $\% 2$ Fdefault $\% 2$ Ffiles $\% 2$ Fdocumento $\% 2$ F $2011 \% 2$ F06 $\% 2 F 154$ gendermainstreaming-science-and-technology-reference-manual-governments-andmainstreaming science-and-technology-reference-manual-governments-andother-stakeholders.pdf\&ei=EUWmVb-WEMjbU7Lqo9AM\&usg=AF(
mDUoSmF8ORqh8AF2yDRw\&sig2=iSFOhUbfHCMn8Okk3TRk1g

McNeil, S.G., Robin, B.R. \& Miller, R.M., 2000, 'Facilitating interaction, communication and collaboration in online courses', Computers and Geosciences 26, 699-708. http://dx.doi.org/10.1016/S0098-3004(99)00106-5

Mdlongwa, T., 2012, 'Information and communication technology (ICT) as a means of enhancing education in schools in South Africa: Challenges, benefits and recommendations', AISA Policy Brief 80, 1-7.

Merriam, S.B., 2009, 'Dealing with validity, reliability, and ethics', in S.B. Merriam (ed.), Qualitative research: A guide to design and implementation, pp. 209-235, Jossey-Bass, San Francisco.

Moletsane, R. \& Reddy, V., 2008, An assessment of the participation of women in se industry for Department of Science and Technology, viewed 10 January 2014, from http://www.hsrc.ac.za/research/output/outputDocuments/5505_Moletsane Assess entoftheparticipationofwomen.pdf

Moon, J.W \& Kim, Y.G., 2001, 'Extending the TAM for a world-wide-web context', Information \& Management 38(4), 217-230. http://dx.doi.org/10.1016/S03787206(00)00061-6

Moore, G.C. \& Benbasat, I., 1991, 'Development of an instrument to measure the perceptions of adopting an information technology innovation', Information Systems Research 2(3), 192-222. http://dx.doi.org/10.1287/isre.2.3.192

Moore, J.L., Dickson-Deane, C. \& Galyen, K., 2011, 'E-learning, online learning, and distance learning environments: Are they the same?', The Internet and Higher Education 14, 129-135. http://dx.doi.org/10.1016/j.iheduc.2010.10.001
Nobel, C., 2007, Women in technology: A call to action, InfoWorld, viewed 16 May 2015, from http://www.infoworld.com/d/developer-world/women-intechnology-callaction-919.

Okazaki, S. \& Renda dos Santos, L.M., 2012, 'Understanding e-learning adoption in Brazil: Major determinants and gender effects', The International Review of Research in Open and Distance Learning 13(4), 91-106.

O’Neill, K., Singh, G. \& O'Donoghue, J., 2004, 'Implementing eLearning programmes for higher education: A review of the literature', Journal of Information Technology 3, 313-323.

Ong, C.S \& Lai, J.Y., 2006, 'Gender differences in perceptions \& relationships among dominantsofe-learningacceptance', Computersin HumanBehaviour22(5), 816-829. http://dx.doi.org/10.1016/j.chb.2004.03.006

Pai, F.Y. \& Huang, K.I., 2011, 'Applying the technology acceptance model to the introduction of healthcare information systems', Technological Forecasting \& Social Change 78, 650-660. http://dx.doi.org/10.1016/j.techfore.2010.11.007

Pallant, J., 2010, SPSS survival manual: A step by step guide to data analysis using SPSS, 4th edn., McGraw-Hill, Maidenhead.

Patton, M.Q., 2002, Qualitative Research and Evaluation Methods, Sage, Thousand Oaks.

Pavon, F. \& Brown, I., 2010, 'Factors influencing the adoption of the World Wide Web for job-seeking in South Africa', South African Journal of Information Management 12(1), Art. \#443, 9 pages.

Pew Internet and American Life Project, 2005, Reports: Demographics, Author Washington, DC, viewed 16 May 2015, from http://www.pewinternet.org/ PPF/r/171/report_display.asp

Pituch, K.A. \& Lee, Y.K., 2006, 'The influence of system characteristics on e-learning use', Computers and Education 47, 222-224. http://dx.doi.org/10.1016/j. compedu.2004.10.007

Razali, N.M. \& Wah, Y.B., 2011, 'Power comparisons of Shapiro-Wilk, Lillefors and Anderson Darling tests', Journal of Statistical Modelling and Analytics 20(1), 21-33.

Reddy, V., Gastrow, M., Juan A. \& Roberts, B., 2013, 'Public attitudes to science in South Africa', South African Journal of Science 109, 1-8. http://dx.doi.org/10.1590/ sajs.2013/1200

Rienties, B., Brouwer, N. \& Lygo-Barker, S., 2013, 'The effects of online professional development on higher education teachers' beliefs and intentions towards learning facilitation and technology', Teaching and Teacher Education 29, 122-131. http://dx.doi.org/10.1016/j.tate.2012.09.002

Robinson, L., Marshall, G.W. \& Stamps, M.B., 2005, 'Sales force use of technology: Antecedents to technology acceptance', Journal of Business Research 58(12) 1623-1631. http://dx.doi.org/10.1016/j.jbusres.2004.07.010

Rubin, H.J. \& Rubin, I., 2005, Qualitative interviewing: The art of hearing data, Sage, Thousand Oaks.

Saadé, R. \& Bahli, B., 2005, 'The impact of cognitive absorption on perceived usefulness and perceived ease of use in on-line learning: An extension of the technology acceptance model', Information and Management 42, 317-327. http://dx.doi.org/10.1016/j.im.2003.12.013

Sánchez, R.A. \& Hueros, A.D., 2010, 'Motivational factors that influence the acceptance of Moodle using TAM', Computers in Human Behavior 26, 1632-1640. http://dx.doi.org/10.1016/j.chb.2010.06.011

Santos, J., 1999, 'Cronbach's alpha: A tool for assessing the reliability of scales', Journal of Extension 37(2), 34-36.

Schoonenboom, J., 2014, 'Using an adapted, task-level technology acceptance mode to explain why instructors in higher education intend to use some learning management system tools more than others', Computers \& Education 71, 247256. http://dx.doi.org/10.1016/j.compedu.2013.09.016

Sierpe, E., 2005, 'Gender distinctiveness, communicative competence, and the problem of gender judgments in computer-mediated communication', Computers in Human Behavior 21(1), 127-145.

Singer, E.E. \& Bossarte, R., 2006, 'Incentives for survey participation: When are they coercive?', American Journal of Preventive Medicine 31, 411-418. http://dx.do. org/10.1016/j.amepre.2006.07.013

South African Government Communications, 1996, White paper on science and technology. South Africa, viewed 16 May 2015, from http://www.dst.gov.za/ publications-policies/legislation/white_papers/Science_Technology_White Paper.pdf

Srite, M. \& Karahanna, E., 2006, 'The role of espoused national cultural values in technology acceptance', MIS Quarterly 30(3), 679-704.

Steyn, H.S., 2000, 'Practical significance of the difference in means', South African Journal of Industrial Psychology 26(3), 1-3.

Steyn, R., 2012, 'Expanding the suite of measures of gender-based discrimination: Gender differences in ablution facilities in South Africa', South African Journal Economic Management Sciences 15(2), 222-234.

Sun, H. \& Zhang, P., 2006, 'The role of moderating factors in user technology acceptance', International Journal of Human Computer Studies 64, 53-78. http:// dx.doi.org/10.1016/j.ijhcs.2005.04.013

Tabachnick, B.G. \& Fidell, L.S., 2007, Using multivariate statistics, Pearson/Allyn \& Bacon, Boston.

Tahmincioglu, M. 2008, 'Your career: Where are the women in tech?', viewed 16 May 2015, from http://www.msnbc.msn.com/id/23033748/print/1/displaymode/1098

Van Zyle, J.M., Heinz, N. \& Nel, D.G., 2000, 'On the distribution of the maximum likelihood estimator of Cronbach's alpha', Psychometrika 65, 271-280. http:// dx.doi.org/10.1007/BF02296146 
Venkatesh, V. \& Davis, F.D., 2000, 'A theoretical extension of the technology acceptance model: Four longitudinal field studies', Management Science 46(2), 186-204. http://dx.doi.org/10.1287/mnsc.46.2.186.11926

Venkatesh, V. \& Morris, M.G., 2000, 'Why don't men ever stop to ask for directions? Gender, social influence, \& their role in technology acceptance \& usage behaviour', MIS Quarterly 24(1), 115-139. http://dx.doi.org/10.2307/3250981

Venkatesh, V., Morris, M.G., Davis, G.B. \& Davis, F.D., 2003, 'User acceptance of information technology: Toward a unified view', MIS Quarterly 27(3), 425-478.
Wasko, M.M. \& Faraj, S., 2005, 'Why should I share? Examining knowledge contribution in electronic networks of practice', MIS Quarterly 29(1), 1-23.

Wild, K.V., Mattek, N., Maxwell, S.A., Dodge, H.H., Jimison, H.B. \& Kaye, J.A., 2012 'Computer related self-efficacy and anxiety in older adults with and withou mild cognitive impairment', Alzheimers Dement 8(6), 544-522. http://dx.doi. org/10.1016/j.jalz.2011.12.008

Wright, W.A., Knight, P.T. \& Pomerleau, N., 1999, 'Portfolio people: Teaching and learning dossiers and innovation in higher education', Innovative Higher Education, 24(2), 89-103. http://dx.doi.org/10.1023/B:IHIE.0000008148.71650.e6 